\title{
"Environmental and economic foundations of system optimization of operational, technological and construction parameters of rice irrigation systems"
}

\begin{tabular}{|c|c|}
\hline AUTHORS & $\begin{array}{l}\text { Vasyl Turchenyuk } \\
\text { Nadiia Frolenkova } \\
\text { Anatolii Rokochynskyi }\end{array}$ \\
\hline ARTICLE INFO & $\begin{array}{l}\text { Vasyl Turchenyuk, Nadiia Frolenkova and Anatolii Rokochynskyi (2017). } \\
\text { Environmental and economic foundations of system optimization of operational, } \\
\text { technological and construction parameters of rice irrigation systems. } \\
\text { Environmental Economics, 8(2), 76-82. doi:10.21511/ee.08(2).2017.08 }\end{array}$ \\
\hline DOI & http://dx.doi.org/10.21511/ee.08(2).2017.08 \\
\hline RELEASED ON & Wednesday, 05 July 2017 \\
\hline RECEIVED ON & Monday, 13 March 2017 \\
\hline ACCEPTED ON & Friday, 19 May 2017 \\
\hline LICENSE & $\begin{array}{l}(c) \text { EY-NG } \\
\text { This work is licensed under a Creative Commons Attribution-NonCommercial } 4.0 \\
\text { International License }\end{array}$ \\
\hline JOURNAL & "Environmental Economics" \\
\hline ISSN PRINT & $1998-6041$ \\
\hline ISSN ONLINE & $1998-605 X$ \\
\hline PUBLISHER & LLC "Consulting Publishing Company "Business Perspectives" \\
\hline FOUNDER & LLC “Consulting Publishing Company "Business Perspectives" \\
\hline
\end{tabular}

NUMBER OF REFERENCES

11

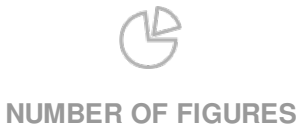

0
NUMBER OF TABLES

2

(C) The author(s) 2022. This publication is an open access article. 
Vasyl Turchenyuk (Ukraine), Nadiia Frolenkova (Ukraine), Anatolii Rokochynskyi (Ukraine)

\title{
Environmental and economic foundations of system optimization of operational, technological and construction parameters of rice irrigation systems
}

\begin{abstract}
The paper substantiates the necessity to carry out system optimization of operational, technological and construction parameters of water regulation in the operation of rice irrigation systems, lays out methodological approaches and results. This research formulates approaches to the selection of project criteria and conditions of economic and environmental optimization during the construction of complex optimization models in the projects of their reconstruction and operation taking into account climatic management strategies of such objects. The proposed set of measures as a result of system optimization is focused on improving the natural and amelioration state of rice irrigation systems, improving their technological and technical parameters, introducing of water and resource saving regimes of rice irrigation and related rice crop rotations.
\end{abstract}

Keywords: system optimization, natural and amelioration regime, rice irrigation system, ecological and economic principles.

JEL Classification: Q15.

Received on: $13^{\text {th }}$ of March, 2017.

Accepted on: $19^{\text {th }}$ of May, 2017.

\section{Introduction}

Problem statement. At the present stage, one of the strategically important and urgent tasks of development of the agrarian sector in Ukraine is the restoration of productivity and resource potential of the rice growing branch, which is impossible without improving the overall technical, technological, economic and environmental efficiency of the existing rice irrigation systems (RIS). The worsening of environmental problems in irrigated agriculture and, especially, in rice growing requires coordination of economic and environmental goals when the most comprehensive ecological and economic results are achieved. This is possible through the introduction of measures aimed at the formation of agricultural systems, which are characterized by ecological stability of the environment and high reproductive capacity based on the use of scientifically-founded and resource-saving technologies of irrigated agriculture.

Analysis of the recent research and publications. The purpose of the modern amelioration of lands should not only be an increase in agricultural production, but also the preservation and

(C) Vasyl Turchenyuk, Nadiia Frolenkova, Anatolii Rokochynskyy, 2017. Vasyl Turchenyuk, Ph.D. inTechnical Sciences, National University of Water Management and Natural Resources, Ukraine.

Nadiia Frolenkova, Ph.D. in Economics, National University of Water Management and Natural Resources, Ukraine.

Anatolii Rokochynskyi, Dr. inTechnical Sciences, National University of Water Management and Natural Resources, Ukraine.

This is an Open Access article, distributed under the terms of the Creative Commons Attribution-NonCommercial 4.0 International license, which permits re-use, distribution, and reproduction, provided the materials aren't used for commercial purposes and the original work is properly cited. improvement in soil fertility under the conditions of the rational use of natural resources and environmental protection (B. S. Maslov, I. V. Minaev, 1985).

Rice systems have a number of features that distinguish them from classical reclamation objects. These features are caused by complex soil, geological and hydrogeological conditions of the territories and the dominance of flooded rice in the rotation of crops. A peculiar feature of the water regulation technology in the growing of flooded rice is the creation and maintenance of the required flushing water regime as a prerequisite for the use of agricultural land ensured by the appropriate modes of water supply and water disposal used to create a layer of water on rice fields according to the biological characteristics and needs of rice culture, as well as filtration and transpiration losses. The essence of the flushing water regime is the reduction of seasonal accumulation of salts in the upper layers and washing out of them by descending water currents into the lower layers and the drainage network. It is important to ensure the necessary level of flushing of rice fields both during the creation and maintenance of a layer of water on them and during their draining for increasing the productivity of rice growing and improving the ecological and amelioration state within the system and in the surrounding area.

In light of the current economic and environmental requirements to such objects, it is necessary to carry out a transition from the usual practice of considering rice irrigation systems not as purely technical, but as complex natural and technical systems with a corresponding change in the whole methodology, technical and technological strategy of their creation and functioning, as well as 
consideration of the changing in time and uncertain climatic conditions, because they, along with the reclamation factors, have a decisive influence on the overall natural and amelioration mode of rice irrigation systems and on the resulting environmental and economic benefits (V. G. Gusakov, A. N. Rokochinskyi, 2016).

As practice and accumulated experience show, the solution of such complex problem for the existing rice irrigation systems, which essentially are also ecological and economic objects (M. I. Romaschenko, A. M. Rokochinskyi, 2010), requires the use of appropriate system solutions to optimize their natural and amelioration regime.

Natural amelioration regime (NAR) (I. P. Aydarov, A. I. Golovanov, Yu. N. Nikolskiy (1990); V. G. Gusakov, A. N. Rokochinskyi (2016)) is a combination of water, air, heat, nutritional, oxidation reduction and other ground regimes, regulated with the help of irrigation and drainage, agro-technical and organizational measures against the background of natural factors of the irrigated system (including rice growing). The main objective of maintaining a favorable natural amelioration regime is to reconcile the requirements of the expanded reproduction of soil fertility and nature conservation under the conditions of intensive agriculture, which ensures the necessary harvests of agricultural crops in compliance with environmental requirements.

Natural amelioration (reclamation) regime is determined by a number of factors, the main of which are the natural (climatic factors), technological factors (supply and drainage of water), construction factors (parameters of the irrigation and drainage network, etc.). The results of the studies (V. A. Stashuk, A. M. Rokochinskyi, L. M. Hranovska, 2014) show that the most significant impact on the natural amelioration regime of the existing rice irrigation systems is affected by the waste drainage network, which in the rice systems determines the intensity and orientation of filtration processes that occur during the prolonged over-wetting of soils under the conditions of irrigation flooding. The natural amelioration network of rice irrigation systems is aimed at the formation of water and salt regimes and, to a significant degree, is a determining factor of productivity of agricultural lands and a guarantor of maintaining a proper environmental and reclamation state of irrigated lands of the rice system.

Goal, objectives and methodology of research. The goal of the paper is to improve the efficiency of rice irrigation systems by optimizing their natural reclamation regime.
To achieve the stated goal, the following problems were solved:

- development of theoretical foundations and modern approaches to system optimization of technical and technological solutions to water regulation of rice irrigation systems on the environmental and economic principles and taking into account different time periods of their reconstruction and operation;

- research, analysis and assessment of operational, technological and technical aspects of water regulation in rice irrigation systems in their relationship with the changing natural and agro-amelioration conditions;

- development of general principles regarding the implementation of models for optimization of technical and technological solutions of water regulation in rice irrigation systems according to the environmental and economic principles;

- improvement of methods of calculation and optimization in solving a complex of forecasting and optimization problems of water regulation in rice irrigation systems in the projects of their construction, reconstruction and operation, implementation and evaluation of their effectiveness.

\section{Research results}

By analogy with V. A. Stashuk, A. M. Rokochinskyi, L. M. Hranovska (2014); V. G. Gusakov, A. N. Rokochinskiy (2016), rice irrigation system is a complex natural and technical ecological and economic system that requires a simultaneous combination of technical, technological, economic and environmental interests based on system optimization. The essence of system optimization is to find all intermediate and local optimums of all major elements of the water regulation technology (pumping stations, water supply network, drainage network, water supply, drainage), all key changing factors in space and time, which affect the efficiency of water regulation and natural amelioration regime of rice irrigation systems in general (climate, topography, crop rotation structure, hydrogeological conditions, etc.) for all levels of implementation of the appropriate model of optimization. According to V. A. Stashuk, A. M. Rokochinskyi, L. M. Hranovska (2014); V. A. Stashuk, A. M. Rokochinskyi, S. P. Mendus, V. O. Turchenyuk (2016), the complex technical and natural ecological and economic systems have a distinct relationship of the effect-mode-technologyconstruction, for rice irrigation systems, system optimization consists in scientific optimization of the parameters of natural reclamation regimes, improvement of the technology of water regulation and construction solutions for their provision. 
Optimization of the natural reclamation regime of rice irrigation systems, based on the need to create and maintain a flushing water regime on the irrigated saline lands as a main factor of ensuring their favorable land improvement conditions, as well as improvement of the general technical, technological, economic and environmental effectiveness of the system, may be reduced to optimization of the intensity of filtration in surface irrigation of rice culture through appropriate relationship between the supply and drainage of water with appropriate irrigation mode. It is the filtration regime, which is formed on the irrigated rice fields during the maintenance of the layer of water in rice cultivation and in the subsequent period, which determines their general environmental and amelioration condition and evaluates the technological efficiency of the drainage network in different periods of operation of rice irrigation systems.

Based on M. I. Romaschenko, A. M. Rokochinskyi (2010); V. G. Gusakov, A. N. Rokochinskiy (2016), considering climatic strategies of management, a system of ecological and economic optimization of operational, technological and construction solutions at the stage of reconstruction of rice irrigation systems can be realized according to the following complex model:

$$
\left\{\begin{array}{l}
Z P_{i k s}^{0}=\min _{\{i\}} \sum_{p=1}^{n p} Z P_{k s p} * a_{p} ; i=\overline{1, n_{i}} ; k=\overline{1, n_{k}} ; s=\overline{1, n_{s}}, \\
Z_{i k s}^{0}=\min _{\{i\}} \sum\left|Z_{j k s p}-\hat{Z}_{j}\right| * a_{p} ; j=\overline{1, n_{j}} ; i=\overline{1, n_{i}} ; k=\overline{1, n_{k}} ; s=\overline{1, n_{s}}
\end{array}\right.
$$

where $Z P_{i k s}^{0}$ are minimal values of reduced costs with a chosen criterion of economic optimality $Z P_{k s p}$ corresponding to the optimal project solution from a set of options $I=\{i\}, i=\overline{1, n_{i}}$;

$Z_{j k s}-$ totality $\{j\}, j=\overline{1, n_{j}}$ of criteria (physical indicators) of ecological efficiency of water regulation in rice irrigation systems according to a set of project solutions $\{i\}, i=\overline{1, n_{i}}$, the appropriate technology of water regulation $\{s\}, s=\overline{1, n_{s}}$;

$\hat{Z}_{j}-$ corresponding indicators of ecological efficiency;

$\alpha_{p}-$ known (established or set) values of repeatability or possible state of typical meteorological regimes in the periods of calculation of aggregate $\{p\}, \quad p=\overline{1, n_{p}}$ within the project period of the object's functioning $\sum_{p=1}^{n_{p}} \alpha_{p}=1$.

Long-term forecasting and optimization calculations should be based on the joint implementation according to the schematized output data and conditions of the real object of hierarchically linked complex of forecasting and simulation models, models of indicators and efficiency criteria, models of technological and technical parameters and models and conditions of optimization of project solutions regarding water regulation of rice irrigation systems (A. M. Rokochinskyi, V. O. Turchenyuk, S. M. Kropivko, S. P. Mendus, 2016; V. G. Gusakov, A. N. Rokochinskyi, 2016).
According to M. I. Romaschenko , A. M. Rokochinskyi (2010), we can consider the indicator of reduced costs $Z P_{i}$ as an economic criterion and conditions for optimization of the construction and parameters of drainage of rice irrigation systems with due regard to weather and climate risk $R_{i}$ with deviation of the water regime of rice fields from optimal levels in the calculation of both autumn and spring periods (presowing) and in the vegetation periods of the system's functioning for the implementation of the relevant options of project solutions of aggregate $\{i\}, i=\overline{1, n_{i}}$

$$
Z P_{i}=Z_{i} \cdot k_{Z_{i}}^{V}=\left[\left(C_{i}+E_{n} K_{i}\right)+R_{i}\right] / V_{i}, i=\overline{1, n_{i}},
$$

where $k_{Z_{i}}^{V}$ - the coefficient of reduced costs $Z_{i}$ by volume (value) $V_{i}$ of the obtained product according to the operational, technological and technical solutions of aggregate $\{i\}, \quad i=\overline{1, n_{i}}$, which is determined by the inverse ratio $1 / V_{i}$;

$C_{i}$ - operating costs for obtaining products according to project solutions;

$E_{n}-$ norm coefficient of economic efficiency of capital investments $K_{i}$ according to the corresponding variants of project solutions;

$R_{i}$ - weather and climate risk according to the corresponding variants of project solutions.

Weather and climate risk, according to M. I. Romaschenko, A. M. Rokochinskyi (2010), is a possibility of losses or shortfall in profits due to the impact of adverse factors during economics activity, or the probability of unforeseen losses of 
the expected profits or income caused by random influence of adverse circumstances, etc. changes in the conditions of economic activity, It is determined by the formula

$$
\bar{R}_{i}=\sqrt{\sum_{j=1}^{m}\left(W_{i j}-\bar{W}_{i j}\right)^{2} * \alpha_{p j}}=\sqrt{\sum_{j=1}^{m} R_{i j}^{2} * \alpha_{p j}}, i=\overline{1, n},
$$

where $W_{i j}$ - the value of gross output according to the actual yields of cultivated crops and obtained by the $i$-th variant of project solutions, $\mathrm{UAH} / \mathrm{ha}$;

$\bar{W}_{i j}$ - the value of gross output according to its potential yield on the site, $\mathrm{UAH} / \mathrm{ha}$.

In formula (2) operating costs $C_{i}$ to produce products consist of agricultural $C_{i}^{A G}$ and operating $C_{i}^{E}$ costs. The latter include deductions for depreciation and maintenance $A_{i}$, reclamation costs $C_{i}^{R}$, monitoring of the system and the costs of water $C_{i}^{W}$ for moisturizing within rice irrigation systems.

Regarding the environmental assessment of reclamation activities, it is an extremely complex issue that has not been resolved for a number of reasons, first of all of objective character, namely because of extreme complexity of determining economic consequences and their negative impact on the environment (Metodychni rekomendatsii schodo ekolohichno optymalnykh rezhymiv meliorovanykh hruntiv humidnoi zony Ukrainy,
2005). Cost-based valuation of environmental factors is always associated with certain conditionality and it is very difficult and sometimes even impossible to calculate in monetary terms the indicators of environmental effects from the realization of land reclamation. That is why there is a need to use and further develop the existing approaches depending on the goals, objectives, complexity and existing information capabilities.

Therefore, similar to V. G. Gusakov, A. N. Rokochinskyi (2016); M. I. Romaschenko, A. M. Rokochinskyi (2010), the definition of environmentally acceptable variants of project solutions regarding rice fields and the system in general can be presented as the necessary conditions and restrictions according to the defined, substantiated and accepted set of physical indicators (criteria) of evaluation of the water, saline and natural reclamation regime of both the rice fields and the system: over the regime of ground waters in pre-sowing period $(\mathrm{Hg})$; the duration of the water depth below the critical depth $(T)$; intensity of filtration processes under the flooded rice fields $(V)$, the degree of salinity of the soil root layer $(S)$; irrigation norm $(M)$; salinity of ground waters $(G)$, and others

$$
Z_{j k s}=\left(H g_{k s}, T_{k s}, V_{k s}, S_{k s}, M_{k s}, G_{k s}\right), \quad j=\overline{1, n_{j}}, k=\overline{1, n_{k}}, s=\overline{1, n_{s}} .
$$

According to such indicators as compared to their maximum values and according to the specific conditions of soil reclamation, it is possible to predict the processes on the rice fields and in the system in general, thereby implicitly evaluating the environmental effect of the reclamation activities. Formally, this can be represented in the complex model (1) or in more detail

$$
Z_{j i}\left\{\begin{array}{l}
\leq \\
= \\
\geq
\end{array}\right\} Z_{j}, \mathrm{j}=\overline{1, n_{\mathrm{j}}}, i=\overline{1, n_{i}} .
$$

Justification of the optimal natural reclamation and groundwater regimes, the relevant technological and technical parameters of project solutions for rice irrigation systems according to the integrated assessment of indicators of their environmental efficiency can be done quite effectively on the basis of the method proposed by B. Karuka (1989).
According to this approach, the characteristic of environmental reliability of variants of reclamation projects can be represented as vector $H$ with components $H_{z}$

$H=H_{z} / z=1,2, \ldots N /$,

where $N$ - the number of elements (factors) that characterize ecological reliability of reclamation project.

Here, components $H_{z}$ take on appropriate values provided that

$$
H_{z}=\left\{\begin{array}{l}
1, \text { if } H_{z} \leq H_{S Z}, \\
0, \text { if } H_{z}>H_{S Z}
\end{array},\right.
$$

where $H_{s z}$ - standard, critical or permissible values of the $z$-th element. 
Assuming that in the system of factors all factors are equally important, it is possible to consider the lack of certain elements as a reduction in environmental reliability.

Then, the coefficient of ecological reliability of reclamation projects can be determined by the formula

$k_{H}=\frac{\sum_{z=1}^{N} H_{z}}{N}$.

In this case, when the components $H_{z}$ take on fixed values "0" or " 1 ", this coefficient represents an approximate assessment of environmental sustainability of the project and the extent of taking into account of the factors of ecological safety of its functioning, especially in terms of maintaining natural reclamation and ground water regimes within the project's period.

In contrast to the studied approach, we offer a more flexible tool for determining the component $H_{z}$, when it takes on more flexible values ranging from 0 to 1 , provided that

$$
H_{z}=\left\{\begin{array}{l}
H_{z}=1-\left(\frac{H_{S Z}-H_{A Z}}{H_{S Z}}\right), \text { if } H_{A Z} \leq H_{S Z}, \\
H_{z}=1+\left(\frac{H_{S Z}-H_{A Z}}{H_{S Z}}\right), \text { if } H_{A Z} \geq H_{S Z}
\end{array},\right.
$$

where $H_{A Z}$ - the actual value of the $z$-th indicator of ecological efficiency;

$H_{S Z}$ - the relevant standard, critical or permissible value that corresponds to $\hat{Z}_{j}$.

This approach to the assessment of ecological safety of the project is different from the classical theory of reliability, which features probability values, but it is quite simple and universal in nature, since depending on the formulation of the problem it makes it possible to use different, mostly expert methods of assessment and different sets of diverse indicators.

Therefore, according to the studied methodology, environmentally optimal general natural reclamation and ground water regimes are provided subject to the restriction that the coefficient of ecological safety of the reclamation project is within the range

$$
0,5<k_{H_{i}} \leq 1,0 .
$$

The proposed scheme of evaluation of environmental reliability of reclamation projects is quite versatile, because, as a constituent element of reliability, it can have any set of both quantitative and qualitative factors characterizing the state of environmental reclamation of a certain territory.

Considering the preliminary results of the studies (V. A. Stashuk, A. M. Rokochinskyi, L. M. Hranovska, 2014), which determine the parameters of use of water and energy for the rational and resource-saving levels of the functioning's efficiency of the Danube region's rice irrigation systems, which make it possible to minimize, compared to the project, the costs of water and energy resources depending on the conditions with heat and moisture and increase the general level of technical operation of rice systems, we have conducted the relevant research of system optimization of natural reclamation regimes, the technologies of water regulation and the basic structural elements of the Danube region's rice irrigation systems regarding the parameters of the drainage network in accordance with the proposed methods.

We have considered the following options for our research:

- option $1 \ldots 3$ - construction and parameters of drainage, according to the recommendations of S. Mendus (2012);

- option 4 ... 8 - improved construction of the drainage network by means of intermediate closed drainage collectors (A. M. Rokochinskyi, V. O. Turchenyuk, S. M. Kropivko, S. P. Mendus, 2016);

- options 9 ... 12 - construction and parameters of the existing drainage network in the form of open channels (V. A. Stashuk, A. M. Rokochinskyi, L. M. Hranovska, 2014).

Optimization of optimal parameters for drainage was carried out considering the optimal parameters of the speed of vertical filtration on rice fields, which reflect the operational and technological aspects of water regulation in rice irrigation systems and the optimal indicator of the share of rice in crop rotation $-50 \ldots 60 \%$.

Calculation of economic indicators was carried out in prices and rates of 2015.

Generalized results of this assessment are summarized in Tables 1, 2. 
Table 1. The main results of optimization of calculations for the Danube region's rice irrigation systems regarding substantiation of the optimal parameters of drainage on rice fields

\begin{tabular}{|c|c|c|c|c|c|c|c|c|c|c|c|}
\hline 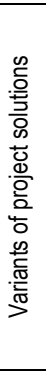 & 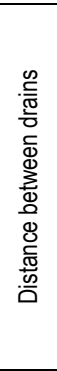 & 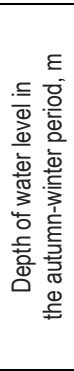 & 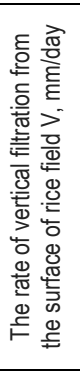 & 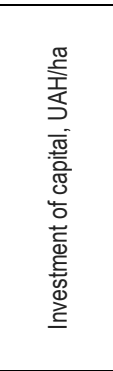 & 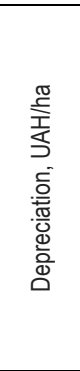 & 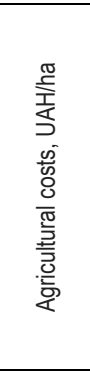 & 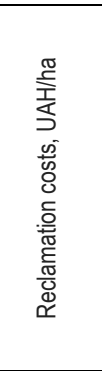 & 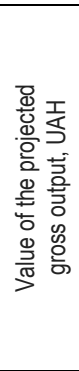 & 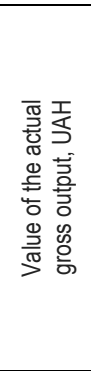 & 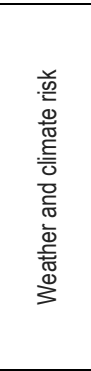 & 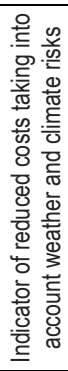 \\
\hline 1 & 50 & 1.86 & 27.1 & 149311.2 & 7465.6 & 10353.0 & 11768.7 & 55800 & 31248.0 & 16663.3 & 2.20 \\
\hline 2 & 75 & 1.78 & 12.0 & 112712.4 & 5635.6 & 11764.9 & 11063.9 & 55800 & 39606.8 & 16193.2 & 1.55 \\
\hline 3 & 85 & 1.75 & 9.4 & 107484.0 & 5374.2 & 13670.6 & 10938.6 & 55800 & 50889.6 & 4910.4 & 1.00 \\
\hline 4 & 100 & 1.59 & 6.8 & 97027.2 & 4851.4 & 14125.8 & 10497.1 & 55800 & 53584.7 & 2215.3 & 0.86 \\
\hline 5 & 125 & 1.49 & 4.7 & 86570.4 & 4328.5 & 13086.3 & 10718.8 & 55800 & 47430.0 & 8370.0 & 1.04 \\
\hline 6 & 150 & 1.35 & 3.0 & 83433.4 & 4171.7 & 12187.1 & 10639.0 & 55800 & 42106.7 & 13693.3 & 1.26 \\
\hline 7 & 175 & 1.23 & 2.2 & 81342.0 & 4067.1 & 10894.9 & 9023.6 & 55800 & 34456.5 & 21343.5 & 1.67 \\
\hline 8 & 200 & 1.11 & 1.7 & 73499.4 & 3675.0 & 10248.3 & 8999.1 & 55800 & 30628.4 & 25171.6 & 1.93 \\
\hline 9 & 225 & 0.95 & 1.3 & 70885.2 & 3544.3 & 9206.8 & 8982.4 & 55800 & 24462.0 & 31338.0 & 2.60 \\
\hline 10 & 250 & 0.83 & 1.0 & 65656.8 & 3282.8 & 8856.3 & 8970.4 & 55800 & 22387.0 & 33413.0 & 2.88 \\
\hline 11 & 300 & 0.60 & 0.7 & 61996.9 & 3099.8 & 7600.0 & 8954.8 & 55800 & 14948.8 & 40851.2 & 4.67 \\
\hline 12 & 500 & 0.40 & 0.3 & 55200.0 & 2760.0 & 7286.1 & 8932.0 & 55800 & 13090.7 & 42709.3 & 5.34 \\
\hline
\end{tabular}

Table 2. Assessment of ecological reliability of project solutions depending on the speed of vertical filtration on rice fields

\begin{tabular}{|c|c|c|c|c|c|c|}
\hline 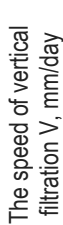 & 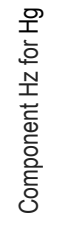 & 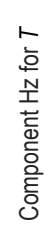 & 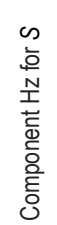 & 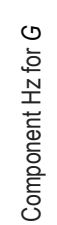 & 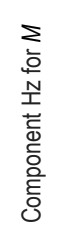 & 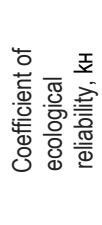 \\
\hline 0.5 & 0.80 & 0.82 & 0.51 & 0.43 & 0.24 & 0.56 \\
\hline 1.0 & 0.95 & 0.98 & 0.55 & 0.50 & 0.28 & 0.65 \\
\hline 2.0 & 1.00 & 1.00 & 0.67 & 0.60 & 0.33 & 0.72 \\
\hline 4.0 & 0.93 & 0.93 & 0.73 & 0.75 & 0.50 & 0.77 \\
\hline 6.0 & 0.87 & 0.89 & 0.80 & 0.86 & 0.61 & 0.80 \\
\hline 8.0 & 0.80 & 0.93 & 0.89 & 1.00 & 0.74 & 0.87 \\
\hline 10.0 & 0.67 & 0.86 & 1.00 & 0.83 & 0.77 & 0.83 \\
\hline 12.0 & 0.70 & 0.86 & 1.00 & 0.73 & 0.77 & 0.81 \\
\hline 14.0 & 0.65 & 0.86 & 0.75 & 0.67 & 0.83 & 0.75 \\
\hline 16.0 & 0.59 & 0.82 & 0.63 & 0.50 & 0.96 & 0.70 \\
\hline 18.0 & 0.50 & 0.79 & 0.50 & 0.33 & 0.91 & 0.61 \\
\hline
\end{tabular}

According to the results of forecasting and optimization calculations, cost-effective variant of project solutions regarding the calculated distance between the drainage channels and additional closed drainage collectors for rice irrigation systems of the Danube region is $100 \mathrm{~m}$. This distance between drainages, as opposed to the current $200 \ldots 500 \mathrm{~m}$ between the open drainage channels, ensures the creation and maintenance of flushing water regime on rice fields with the optimal intensity of vertical filtration $6 \quad \ldots 8 \mathrm{~mm} /$ day. Compared to $\mathrm{S}$. Mendus (2012) who, on the basis of hydro-mechanical method of calculation, determined the required distance between the systematically closed drainage $70 \ldots 75 \mathrm{~m}$, the method of optimization makes it possible to achieve the economic effect $-1343,5$ UAH per hectare of the rice system.

The expediency of the proposed project solutions, which are aimed at improving the level of drainage of rice fields as the main condition for the creation of the flushing water regime, which is related, in general, to the effective functioning of rice irrigation systems, is confirmed by the assessment of their environmental safety. Thus, the coefficient of environmental reliability in the creation and maintenance of the necessary level of flushing on rice fields during the period of vegetation $6 \ldots 8 \mathrm{~mm}$ /day is $0.80 \ldots 0.87$, which meets the necessary requirements.

\section{Conclusion and recommendations for further research}

System optimization of the natural reclamation regime of rice irrigation systems on ecological and economic principles makes it possible to improve the general efficiency in the functioning of rice irrigation systems taking into account economic and environmental requirements through the coordination of parameters, the level of structural and environmental reliability and the cost of these solutions with the level of the generated effect during their realization.

Undoubtedly, the obtained general recommendations should be clarified for the conditions of each real object, which would be considered according to the relevant technical, economic and environmental indicators. 


\section{References}

1. Aydarov, I. P., Golovanov, A. I., Nikolskiy, Yu. N. (1990). Optimizatsiya meliorativnykh rezhimov oroshaemykh I osushaemykh selskokhoziaistvennykh zemel (rekomendatsii). Moskva: Agrometeoizdat, 60 p.

2. Frolenkova, N. A., Kozhusko, L. F., Rokochinskyi, A. M. (2007). Ekoloho-ekonomichne otsinuvannia v upravlinni melioratyvnymy proektamy. Rivne: NUVHP, 257 p.

3. Gusakov, V. G. (Ed.) et al., Rokochinskiy, A. N. (2016). Proceedings from: Mezhdunar. nauchn. konf. Minsk: Belaruskaya navuka.

4. Karuk, B. P. (1989). Ekologicheskoe obosnovanie proektov meliorativnykh sistem. Kiev: VIPK Minvodstroya SSSR, $110 \mathrm{p}$.

5. Maslov, B. S., Minaev, I. V. (1985). Melioratsiya i okhrana prirody. Moskva: Rosselkhozizdat, 271 p.

6. Mendus, S. P. (2012). Obhruntuvannia neobkhidnosti ta posylennia drenovanosti polyvnykh kart rysovykh system (na prykladi Prydunaiskykh rysovykh zroshuvalnykh system) (Dissertation abstract). Rivne.

7. Metodychni rekomendatsii schodo ekolohichno optymalnykh rezhymiv meliorovanykh hruntiv humidnoi zony Ukrainy (2005). Rivne: NUVHP, 50 p.

8. Rokochinskyi, A. M., Turchenyuk, V. O., Kropivko, S. M., Mendus, S. P. (2016). Patent na korysnu model nomer 104000, E 02 B 13/00, 11/00. Karta - chek rysovoi systemy z zakrytoiu drenoiu-kolektorom, Bul. nomer 1.

9. Romaschenko, M. I. (Ed.), Rokochinskyi, A. M. (2010). Naukovi ta praktychi aspekty optymizatsii vodorehuliuvannia osushuvanykh zemel na ekoloho-ekonomichnykh zasadakh. Rivne: NUVHP, $351 \mathrm{p}$.

10. Stashuk, V. A., Rokochinskyi, A. M., Hranovska, L. M. (2014). Rys v Ukraini. Kherson: Hrin, D. S., 976 p.

11. Stashuk, V. A., Rokochinskyi, A. M., Mendus, S. P., Turchenyuk, V. O. (Eds.). (2016). Rys Prydunavia. Kherson: Hrin, D. S., 620 p. 